\title{
THE SOLAR RENEWABLE ENERGY SYSTEM STUDY WITH A CAPACITY OF 1300 W UTILITIZING POLYCRYSTALLINE PHOTOVOLTAIC
}

\author{
Armin Sofijan ${ }^{1}$ \\ ${ }^{1}$ Electrical Engineering Department, Faculty Engineering, Sriwijaya University
}

\begin{abstract}
Solar energy is one of the alternative energy that is environmentally friendly and cheap raw materials and available throughout the year as a substitute for conventional energy whose raw materials are getting thinner and have a bad impact on the environment such as air pollution, noise and hazardous waste for the environment over a long period of time, solar energy has great potential as an independent solar power plant, which offers solutions to provide electricity to meet electricity needs, especially in areas not yet covered by the electricity grid of the National Electric Company. The $1300 \mathrm{~W}$ solar power plant is planned to use polycrystalline solar panels with a capacity $100 \mathrm{WP}$, combined with battery components and inverters, it can generate AC current for daily electricity needs. The greater the electrical load, the faster the battery life. This research shows that it takes 60 polycrystalline solar panels for 12 hours, 26 Solar Chargers 15 A, 9 batteries with a capacity of $150 \mathrm{Ah}$, and 15 Inverters $1300 \mathrm{~W}$.
\end{abstract}

Keywords: Solar power plant, Solar Home System, Solar Panel

\section{INTRODUCTION}

The latest, photovoltaic is a solar panel that is used in housing as a solar power plant which is a solar renewable energy system in general PV solar system for residential homes [1] [2] Solar renewable energy systems in home-scale and independent stand-alone power plant planning are not connected to other plants are called offgrid systems Design considerations of standalone solar photovoltaic here is not yet mentioned the type and capacity of PV [3][4][5][6].

New renewable energy is very important because non-renewable energy such as petroleum, coal and gas are limited. Solar energy is a source of energy that is widely available in Indonesia because it has a tropical climate. This energy does not produce pollution, clean or environmentally friendly. Solar energy is one of the most popular forms of renewable energy. The use of solar panels is increasing rapidly throughout the world. Renewable energy is becoming more developed now.

Photovoltaic panels are solar panels that are used in homes as solar power plants. This panel is a renewable solar energy system for residential houses. Solar energy systems are used on a home scale and stand alone. Meanwhile, independent power plant planning that is not connected to other plants is called an off-grid system and vice versa, is called an on-grid system.

Many researchers present procedures for designing stand-alone photovoltaic systems [2] [3] [4]. As researchers [5] who introduced the procedures used in constructing and selecting equipment from stand-alone photovoltaic systems based on watt-hour demand.

The photovoltaic effect is a phenomenon in which the emergence of an electric voltage due to the connection or contact of two electrodes connected by a solid or liquid system when obtaining light energy. Solar Power Plants (SPP) utilize sunlight to produce DC (Direct Current) electricity that can be converted into AC (Alternating Current). SPP can be designed to meet the needs of small to large energy, both independently and with hybrid systems, both with Stand Alone / Off-Grid or Grid Connected / On-Grid. Off-Grid systems are generally used in remote areas that are not covered by the electricity network. Some off-grid system products include SHS, PJUTS, and communal SPP for large scale systems [3]. SHS is an

*Corresponding author’s email: a_sofijan@ft.unsri.ac.id 
independent solar power generation system, which offers solutions to provide electrical power to meet the electrical needs of household appliances, lighting, computers, and others. Especially in areas not yet reached by government power plants. The electricity network usually consists of several solar panels, solar charging controllers to regulate the current to protect batteries from overcharging and equipment from damage. The battery is used to store the energy produced by the panel for the night or when the sun is not shining, and the inverter to convert $12 \mathrm{~V}$ DC voltage to $220 \mathrm{~V}$ AC voltage. This can be combined with backup sources such as government power plants if needed, using a simple to automatic switching system.

Benefits of using Solar Home System as solar renewable energy system.:

- Easy to install Using simple equipment and does not require special skills.

- Easy to operate the system works without fuel and no requires special operation.

- Long durability the system has been proven to work well continuously for approximately.

For this reason, Figure 1 has explained the PV panel system that can generate electricity for households.

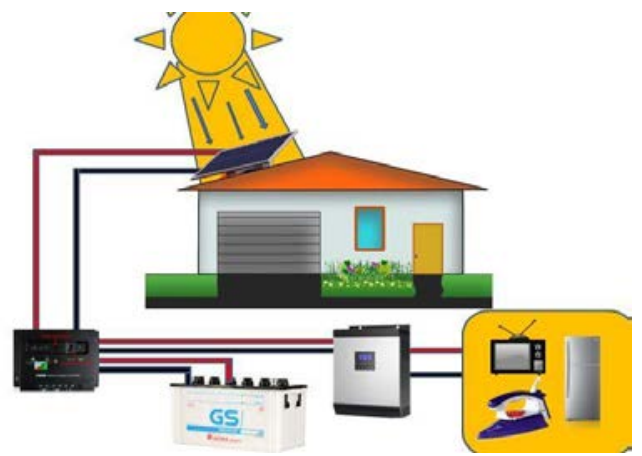

Figure 1. Solar Renewable Energy System

This article explains the use of PV panels for a system that capable of delivering electricity for the needs of a household. PV panel capacity used is $1300 \mathrm{Wp}$ with polycrystalline type. This test was carried out on the campus of Sriwijaya University in Inderalaya, South Sumatra, Indonesia.

\section{METHODOLOGY/ EXPERIMENTAL}

Solar Home System (SHS) consists of several components, solar panel, solar charge control (SCC), battery, inverter, and load (Figure 2.).

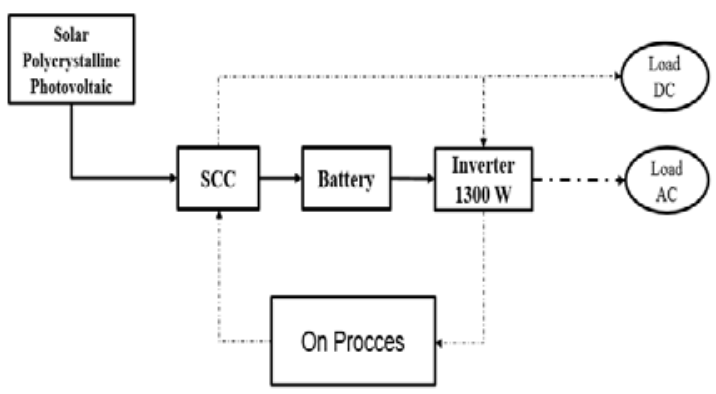

Figure 2. Block Diagram Solar Renewable Energy System

Solar Panel

Generally, solar cells are made of semiconductor material. Solar cells are an important component in converting solar energy into electrical energy. The area of this solar cell is around $10-15 \mathrm{~cm} 2$. Solar cells utilize sunlight to produce DC currents, these DC currents can be converted into AC currents using an instrument, namely an inverter. The solar cell is a thin layer made of pure silicon (Si) and other semiconductor materials. The electricity produced by a single solar cell is very small. Therefore, some solar cells need to be combined into components called solar modules or PV panels. These panels are generally produced by solar cell factories [5].

The Fill Factor size can be calculated using the following equation:

$F F=\left(V_{M P} \cdot I_{M P}\right) /\left(V_{O C} I_{S C}\right)$

$F F=P_{M P} / V_{O C} \cdot I_{S C}$

$\mathrm{V}_{\mathrm{MP}}, \mathrm{I}_{\mathrm{MP}}, \mathrm{V}_{\mathrm{OC}}, \mathrm{I}_{\mathrm{SC}}$ are Maximum Voltage, Maximum current, power, Open Circuit Voltage and Short Circuit Current.

The types of solar panels currently available in the market are as follows: Monocrystalline, polycrystalline, and Amorphous Silicon.

\section{Monocrystalline}

Monocrystalline type solar cells use pure silicon crystal rods. These pieces of solar cells are identical to each other so that they have a high level of efficiency (equal to 15-25\%). Physically, this solar cell has a dark black color and there will be an empty cavity or part of one solar cell 
with another if arranged into solar panels. This happens because the solar cells used are cut slightly in each corner and round or rectangular which can make a loss because of it. It can reduce the energy produced in this type. The high price is also one of the considerations in choosing this type of solar cell [6].

2. Polycrystalline

Polycrystalline solar cell consists of melted silicon rods printed into a square shape (Figure $3)$. This type of solar cell has a low efficiency level of around 13-16, because the solar cells do not have identical shapes with each other. Physically, the color is a blue and it does not have a cavity or empty area if it is arranged on a solar panel because of its square shape. The price of this type so cheap and the manufacturing process is easier than monocrystal solar cells. Thus, many people consider choose this type of solar cell. Moreover, this type of solar cell can also work well in cloudy conditions [6].

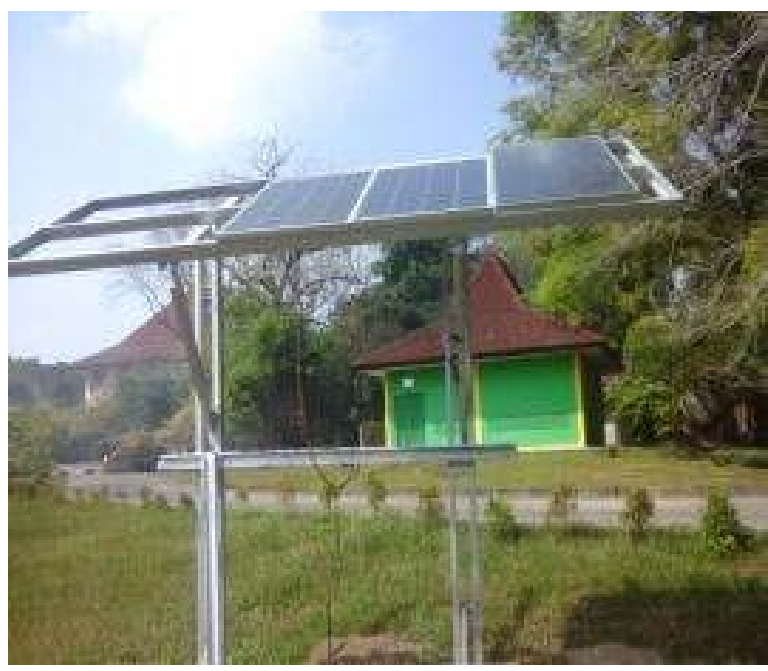

Figure 3. Polycrystalline tipe panel

\section{Amorphous Silicon}

Amorphous solar cell is made from amorphous silicon material which is stacked in layers to form solar cells. This type of solar cell has the lowest efficiency around 8 - 11\% compared to the previous 2 types. The material in this solar cell was originally used on watches and calculators before the development of manufacturing technology in solar cells. Although, the price is so cheap, this type of solar cell is rarely used because the efficiency is too small compared to other types of solar cells [7].
Next, the equipment used in a solar power plants is the Solar Charge Control (SCC) [8][9]. Solar Charge Controller is one of the electronic equipment used in solar power plants. This equipment plays a role to protect the battery by preventing reverse current to the solar module, protect against the short circuit, regulate the DC current flowing into the battery and leading from the battery to the load so that it does not experience overcharging (excessive battery capacity) as well as overvoltage. When the battery is fully charged, the electricity obtained from the solar panel will not flow to the battery (open circuit), and when the battery is less than $25 \%$, the charge controller will charge the battery so that it may become fully charged (closed circuit). The types of solar charge controller are as follow: simple and pulse.

1. Simple

Simple type charge controller depends on the relay or switching transistor to control the voltage into the battery. When the voltage has reached the specific limit, the voltage will be disconnected from the battery. When it reaches the lower limit of the required voltage, the voltage will be reconnected to the battery. Simple type charge controller depends on the relay or switching transistor to control the voltage into the battery. When the voltage has reached the specific limit, the voltage will be disconnected from the battery. When it reaches the lower limit of the required voltage, the voltage will be reconnected to the battery.

\section{Pulse}

This type of charger uses PWM (Pulse Width Modulation) technology to recharge the battery. It works by sending pulses continuously to the battery. The pulse is to "On-Off" switch. The controller constantly checks the status of the battery to find out how fast the pulse is sent and how wide the pulse is. When the battery are full and do not have any load, the sent pulse width is short and the delivery time span is a little longer. When the battery condition is empty, the pulses sent are very wide and with a fast time span [8].

Other equipment needed by a solar power plants is a battery and an inverter. Battery a stores electrical energy produced from solar panels through an electrochemical process. The electrochemical process changes the battery chemistry to electricity (emptying process) and electricity becomes chemical by regenerating 
electrodes on the battery and by passing an electric current in the opposite direction of cell polarity [9], [10]. Lead acid batteries are a tested technology that has been used in off-grid energy systems for decades. While they have a relatively short life and lower DoD than other battery types, they are also one of the least expensive options currently on the market in the home energy storage sector. For homeowners who want to go off the grid and need to install lots of energy storage, lead acid can be a good option.

Inverter is used to convert the electrical energy stored in DC current the into AC current. The inverter converts 12-24V DC current from devices such as batteries or solar cells to $220 \mathrm{~V}$ AC current [11],[12].

Solar Panel Calculations.

Power, Current and Voltage are produced in the adsorption of Solar Energy towards the Solar Panel. voltage and current may result power which can be calculated using the following equation:

$P=V . I . F F$

$\mathrm{P}, \mathrm{V}, \mathrm{I}, \mathrm{FF}$ are power, voltage, current, fill factor respectively.

The average Power of a Solar Panel Calculations. $P_{1}+P_{2}+P_{3} \ldots .+P_{n}$

$\mathrm{P}_{\mathrm{n}}, \mathrm{n}$ is research power to $\mathrm{n}$, number of studies.

The Panel's Generated Power Calculations.

The power that able to be generated within a period of 1 hour can be calculated as follows, namely solar panel needs, requirements of solar charge controller, battery requirements, and battery capacity.

The Need for a Solar Panel against the load that will be generated can be determined as follows:

$n=\frac{P}{P_{\text {Panel }}}$

P, Panel, $n$ are power on load, power panel, and number of panels.

The Solar Charge Controller needs are calculated based on the characteristic and specifications of the Solar Panel as follows:

$I=n \cdot I_{S C}$

I, n, Isc are current (A), number of panels (units), and short circuit current (A).
The need for minimum batteries for $1300 \mathrm{~W}$ in 12 hours battery can be calculated using the following formula:

$n=\frac{P . t}{V_{b a t} \cdot C_{b a t}}$

$\mathrm{C}_{\text {bat, }}, \mathrm{t}, \mathrm{V}_{\text {bat }}$ are battery capacity (Ah), time of life load (hours), and voltage on the battery (Volt).

The capacity of the battery used without Solar Panels to deliver energy is as follows:

$C_{\text {bat }}=\frac{D \cdot P}{V_{\text {bat }} \cdot D o D \cdot \eta}$

P, D, DoD, $\eta$ are usage load, autonomy load, maximum depth of battery discharge, and battery efficiency.

Inverter capacity:

$C_{i n v}=P M P P . n$

PMPP, $\mathrm{n}$ are power output of solar module (Watt), number of samples.

Research methods used are as follows, namely literature review, discussion of method, and observation method. Next, this research include the process of design and assembling Solar Home System with following steps, namely designing and assembling, testing tools, and data processing.

\section{RESULT AND DISCUSSION}

Solar Home System measurement results are shown in table 1.

Table 1 Measurement Tuesday, August 7, 2018

\begin{tabular}{ccccc}
\hline Time & $\begin{array}{c}\text { Average } \\
\text { Voltage } \\
(\mathrm{V})\end{array}$ & $\begin{array}{c}\text { Average } \\
\text { Current } \\
(\mathrm{A})\end{array}$ & $\begin{array}{c}\text { Temp. } \\
\left({ }^{\circ} \mathrm{C}\right)\end{array}$ & $\begin{array}{c}\text { Power } \\
(\mathrm{W})\end{array}$ \\
\hline $07: 00$ & 56.8 & 0.136 & 24 & 6.378 \\
\hline $08: 00$ & 59.7 & 0.672 & 26 & 8.165 \\
\hline $09: 00$ & 58.2 & 0.346 & 32 & 21.670 \\
\hline $10: 00$ & 58.5 & 0.782 & 33 & 24.427 \\
\hline $11: 00$ & 58.5 & 0.396 & 43 & 20.137 \\
\hline $12: 00$ & 60.8 & 1.026 & 39 & 20.211 \\
\hline $13: 00$ & 60.0 & 1.110 & 38 & 30.606 \\
\hline $14: 00$ & 60.0 & 1.459 & 44 & 32.635 \\
\hline $15: 00$ & 58.4 & 0.513 & 35 & 38.419 \\
\hline $16: 00$ & 58.0 & 0.320 & 34 & 17.509 \\
\hline & & & &
\end{tabular}




\begin{tabular}{ccccc}
\hline $17: 00$ & 56.1 & 0.152 & 31 & 5.967 \\
\hline $18: 00$ & 45.7 & 0.083 & 28 & 0.439 \\
\hline & & & Total & 266.571 \\
\hline
\end{tabular}

Furthermore, the results of measurement of the Solar Home System the next day are shown in Figure 4, Figure 5, and Figure 6.

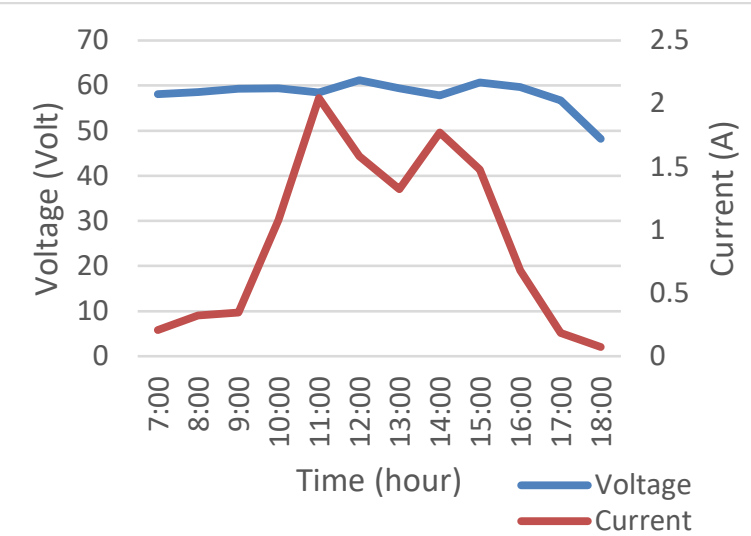

Figure 4. Data current and voltage August 8, 2018

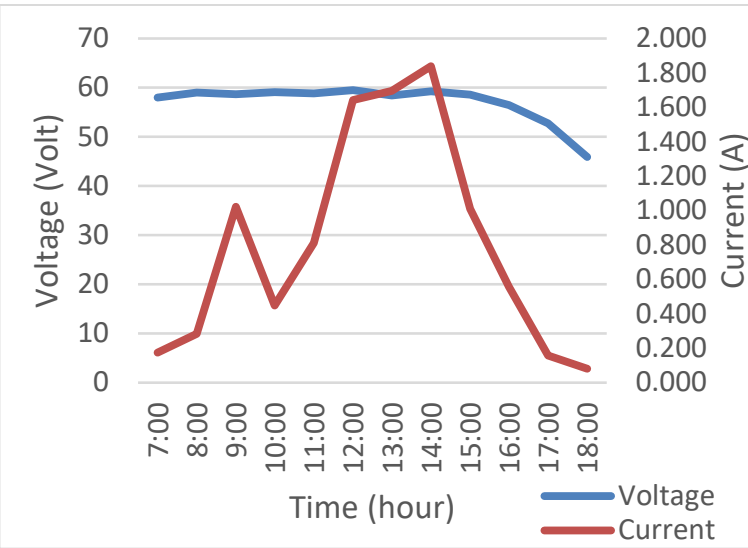

Figure 5. Data Current and Voltage August 19, 2018

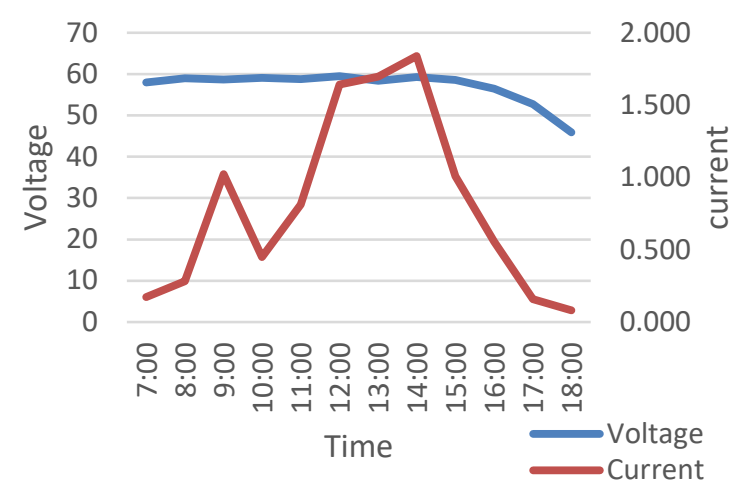

Figure 6. Data Current and Voltage August 20, 2018

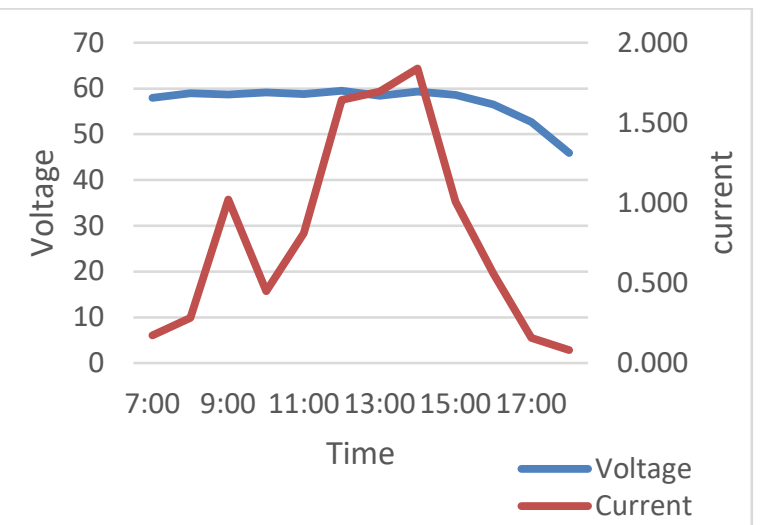

Figure 7. Data current and voltage August 21, 2018

The test results show that solar radiation coming to the surface of the PV panel is low at 07:00 to $11: 00$ in the morning, but there is an increase in solar radiation from 11:00 to $14: 00$ and decreases again after that until 18:00. The test results shows that solar radiation coming to the surface of the PV panel is low at 07:00 to 11:00 in the morning, but there is an increase in solar radiation from 11:00 to 14:00, and decreases again, until 18:00. This event is a difficulty to be able to produce high radiation due to several factor, namely dust, and particles in the air that prevent sunlight from penetrating these layers. In general, incoming solar radiation can be direct or diffuse. Therefore, the voltage and current generated will follow the amount of solar radiation received by the PV panel. When solar radiation decreases, voltage and current go down. In general, the power generated will also decrease following the voltage and current generated by the PV panel. For this reason, the weather conditions is a determinant of power output by the PV Panel.

The next, the discussion consisted of a discussion of components for planning the manufacture of Solar Renewable Energy Systems using renewable energy, namely solar power components used for making Solar Renewable Energy System. It is a components that has been provided in the market, such as Solar Charge Controller, $12 \mathrm{~V}$ Battery with a capacity of 150 Ah, 1300 W Inverter and Polycrystalline 100 WP Solar Panel.

The research this time will be carried out in the Energy Laboratory at Sriwijaya University Indralaya, voltage measurements on the panel, current on the panel, inverter output voltage, inverter output current, and calculating how many solar, SCC, inverter and battery panels for 
electricity needs with 1300 watts of power and in the battery and panel endurance tests provided. The research starts from August 7 to August 21, 2018.

Total and Average Power of the Solar Panel at battery. Charging in retrieving data carried out at the Energy Technology Research Laboratory, the purpose of data collection is to calculate the power generated by the Solar Panel to become a Solar Renewable Energy System . On use one Polycrystalline 100 Wp Solar Panel, power generated from Solar Energy in 15 days of data collection, including in table 2.

Table 2. Total and average power of the solar panel on charging battery

\begin{tabular}{ccc}
\hline Day & Date & $\begin{array}{c}\text { Total Power } \\
(\mathrm{W})\end{array}$ \\
\hline Tuesday & 07 August 2018 & 266.571 \\
\hline Wednesday & 08 August 2018 & 332.568 \\
\hline Thusrday & 09 August 2018 & 279.356 \\
\hline Friday & 10 August 2018 & 384.202 \\
\hline Saturday & 11 August 2018 & 367.809 \\
\hline Sunday & 12 August 2018 & 234.379 \\
\hline Monday & 13 August 2018 & 303.207 \\
\hline Tuesday & 14 August 2018 & 226.573 \\
\hline Wednesday & 15 August 2018 & 332.326 \\
\hline Thusday & 16 August 2018 & 279.536 \\
\hline Friday & 17 August 2018 & 384.202 \\
\hline Saturday & 18 August 2018 & 367.803 \\
\hline Sunday & 19 August 2018 & 342.705 \\
\hline Monday & 20 August 2018 & 296.971 \\
\hline Tuesday & 21 August 2018 & 351.041 \\
\hline & Total & $4,771.28$ \\
\hline Average & 318.085
\end{tabular}

On Fig 4 and table 1 , the first day the data collection is generated $266.571 \mathrm{~W}$ due to cloudy weather, on Fig 5, the second day the power produced was 332,326 $\mathrm{W}$ better than the power produced on the first day. On Fig 6, the third day the power was reduced due to cloudy weather and the power produced was $279,536 \mathrm{~W}$, the fourth day on Fig 7, the power generated increased again to 384,202 W, On Fig 4 until Fig 7 , the highest power generated during 15 days of data collection, because the fifteenth days the power produced decreased slightly to 351,041 W.

\section{CONCLUSION}

Based on the calculations and analysis have been carried out, the conclusions are as follows:

- Power generated by 100 WP solar panels Polycrystalline in 15 days testing reached $4771.28 \mathrm{~W}$, or per day reaching $318.085 \mathrm{~W}$.

- To generate 1300 Watts of power in 12 hours, it takes at least 60 unit Polycrystalline Solar Panels with a capacity of 100 WP, 26 unit Solar Charge Controller, 9 unit batteries 12V 150Ah, 15 unit Inverter.

\section{ACKNOWLEDGEMENT}

Acknowledgments were conveyed to fellow researchers and Sriwijaya University institutions who have supported this research.

\section{REFERENCES}

[1] M. Nassereddine, M. Nagrial, J. Rizk, and A. Hellany, "PV solar system for residential homes: PV panel tracking system using electronic circuits,” 3rd Int. Conf. Electr. Biomed. Eng. Clean Energy Green Comput. EBECEGC 2018, pp. 39-42.

[2] W. Ali, H. Farooq, A. U. Rehman, Q. Awais, M. Jamil, and A. Noman, "Design considerations of stand-alone solar photovoltaic systems," 2018 Int. Conf. Comput. Electron. Electr. Eng. ICE Cube 2018, no. February 2019, pp. 1-6.

[3] J.Aggarwal and M. L. Aggarwal, "Harnessing Solar Energy for Every Home: Energy Saving Applications," Conf. Pap. Sci., vol. 2014, pp. 13.

[4] D. a Aremu, "Design Of Stand-Alone Solar Photovoltaic System For Residential Buildings," Int. J. Sci. Technol. Res., 2013, vol. 2, no. 12, pp. 187-194.

[5] J Orebiyi, B. Barnes, and K. S. Das, "Dyesensitized solar cells," Proc. LACCEI Int. Multiconference Eng. Educ. Technol., vol. 2018-July.

[6] Electrical properties mono- and polycrystalline silicon solar cells," J. Achiev. Mater. Manuf. Eng., vol. 59, no. 2, 2013 pp. 6774 ,

[7] A.Le Donne, A. Scaccabarozzi, S. Tombolato, S. Binetti, M. Acciarri, and A. Abbotto, "Solar Photovoltaics: A Review Solar Photovoltaic: A Review,” Am. Sci. Publ., vol. 2., no. November 2014, pp. 1-9..

[8] C. A. Osaretin and F. O. Edeko, "Design and Implementation of a Solar Charge Controller with Variable Output,” J. Electr. Electron. Eng., vol. 12, , 2015 pp. 40-50. 
[9] F. Faithpraise, D. Bassey, M. Charles, O. Osahon, M. Udoh, and C Chatwin, "Experimental design and construction of an enhanced solar battery charger," IOSR J. Electron. Eng., vol. 11, no. 2, pp, 2016, 11-16 [10] M. I. T. Electric and V. Team, "A Guide to Understanding Battery Specifications," 7 Decembers, 2008.
[11] C. S. kanya, L. P. anga, K. J. hanan, and T. S. P. admanabhan, "A New Self-Balancing Cascaded Multilevel Inverter for Level

Doubling Application,” Int. J. Adv. Res. Electr. Electron. Instrum. Eng., vol. 04, no. 02, 2015 pp. 795-802.

[12] A. Monitoring, "PWM inverter circuit Get DailyUpdates via Email Enhance,” 2016. pp. 1-26, 